\title{
FRAGMENTATION AND CONFLICT AMONG ISLAMIC POLITICAL PARTIES IN INDONESIA DURING REFORMASI ERA (1998-2009) Anatomy, Factors and Implications
}

\author{
Sri Yunanto and Ahmad Fauzi Abdul Hamid \\ Universiti Sains Malaysia, Penang - Malaysia
}

\begin{abstract}
Since independence of the Republic of Indonesia, Muslims, as the majority population, have established diverse Islamic political parties. The nature of such parties has changed from the days of the Old Order to the New Order and Reformasi eras. Despite similar anatomies between Islamic parties of the Old Order and those of Reformasi, Islamic political parties profess different ideological missions. While the beginning of Old Order saw the confederation of Islamic political parties, Masyumi, seeking to promote the establishment of an Islamic State, none of the Islamic political parties which mushroomed during Reformasi era expressly struggled for the establishment of an Islamic state. However, the Islamic political parties had to weather similar problems of internal conflict and fragmentation. Different ideological strands, policy stances and leadership styles are believed to be amongst the pivotal root causes of their domestic troubles. With their popular votes and parliamentary seats significantly reduced, they prove to be no competition to the nationalist political parties.
\end{abstract}

Keywords: Islamic political parties, reformasi era, conflict.

\section{Introduction}

Since the era of Dutch colonization, Islam in Indonesia has displayed the character of being not only a social movement but also a political force to be reckoned with. Series of armed resistence were campaigned by Muslims of the archipelago against the colonial masters. From the early of the twentieth century onward, the avenue of 
resistance of Muslims was not only manifested in armed-struggles against the colonial forces, but also in form of political parties. Islamic parties have distinguished themselves as important political institutions which struggle for the interests of Muslims as the majority population of Indonesia. However, from the onset of the Old Order until the tumultuous period of Reformasi, Islamic politics has been beset with chronic instability, with recurring instances of fragmentation and conflict coloring the dynamics of intra-Muslim politics. As a result, as well as for ideological motive, the fact that Islam is the the religion of majority of Indonesian population does make Islamic parties as dominant parties in Indonesia. In fact, the trend shows a continuous decrease of voters.

In retrospect, Islam's role as an organized unit of political identification locates an early history to the colonial-era founding of Sarekat Islam (SI) by H.O.S. Cokroaminoto in 1912, originally as a vehicle to fight for the interests of Muslim traders. A host of Islamic parties followed suit since Indonesia gained national independence. On 7-8 November 1945, Muslims formed a political confederation in the form of Majelis Syuro Muslimin (Masyumi), which synergized the energies of four main Islamic organizations in Indonesia, viz. Nahdlatul Ulama (NU), Muhammadiyah, Perikatan Umat Islam dan Persatuan Umat Islam. However, within a period of just two years from the first PEMILU, the seeds of fragmentation and intra-Muslim wrangling had come out in the open. Partai Syarikat Islam Indonesia (PSII), a Masyumi component, left to form its own party, motivated by the desire to gain a ministerial post in Amir Syarifudin's cabinet. ${ }^{1}$ Five years later, in 1952, NU also broke away from Masyumi and established Partai NU. Three factors undergirded NU's decision to organizationally separate itself from Masyumi. First, Masyumi politicians who were generally Muslim modernists were said to be inclined to look down on traditionalist NU politicians. ${ }^{2}$ Second, Masyumi political elites were set on the Muhammadiyah figure Faqih Usman as their choice of the Minister of Religious Affairs, a position seen by NU politicians as their cherished domain. Third, Masyumi politicians had unilaterally weakened the authority of the NU-led

1 Lili Romli, Islam Yes, Partai Islam Yes: Sejarah Perkembangan Partai-Partai Islam di Indonesia (Pustaka Pelajar: Pusat Penelitian Politik LIPI, 2006), pp. 35-36.

2 Ali Haidar, Nabdatul Ulama dan Islam di Indonesia (Jakarta: Gramedia Pustaka Utama, 1998), p. 105. 
Dewan Penasihat (Dewan Shuro), by transforming its role from a decision-making body to a mere advisory council. ${ }^{3}$

Nevertheless, in 1955 general election, results of the inaugural general elections (PEMILU: Pemiliban Umum) of 1955 showed that the strength of Islamic parties was not to be under-estimated. ${ }^{4}$ They clinched a popular vote tally of $43.71 \%$, not far off from the $46.86 \%$ achieved together by nationalist parties such as Partai Nasionalis Indonesia (PNI), Ikatan Pendukung Kemerdekaan Indonesia (IPKI), Partai Komunis Indonesia (PKI), Partai Sosialis Indonesia (PSI) and other pluralist parties. ${ }^{5}$ While Nahdlatul Ulama was mainly a Javabased party, Masyumi emerged as the strongest Islamic force in the 1955 PEMILU, harvesting support from $20.92 \%$ of the electorate and winning in ten of the overall fifteen electoral districts, including Jakarta Raya (26.12\%), South Sumatera (43.13\%), Central Sumatera $(50.77 \%)$, North Sumatera (37\%), West Kalimantan (33.25\%), South East Sulawesi (39.98 \%) and Maluku (35.35 \%). ${ }^{6}$ After Soekarno promulgated his scheme of Guided Democracy in 1959 and dissolved Masyumi in 1960, ${ }^{7}$ NU, PSII and PERTI coalesced under the Muslim League, which by and far backed Soekarno's ideological tool of NASAKOM. NU sources insist that such support was designed to specifically countervail PKI's then burgeoning influence on Soekarno. Based on such a strategy, NU created youth, labour, agriculturalist and cultural organizations parallel to the existing structure of PKI ${ }^{8}$

At the outset of Suharto's New Order (1965-1998), Muslim politicians hoped for new opportunities to advance the cause of Islamic parties in Indonesia. Unfortunately, such lofty hopes were dashed as the authoritarian Suharto was not interested in democracy and relied heavily on the bureaucracy and military in his approach to development. Political stability became the foundation of his

3 Ibid., p. 37 and p. 105.

${ }^{4}$ Romli, Islam Yes, Partai Islam Yes, pp. 35-36.

5 Bambang Setyawan, "Pergeseran Kekuatan Partai Nasionalis dan Islam, 1955-2004," Kompas, September 15, 2008.

${ }^{6}$ Ibid.

${ }^{7}$ Based on Kepres No.128 year 1960, the only parties officially recognized by the state were PNI, NU, PKI, Partai Katolik, Partai Indonesia (Partindo), PSII, Partai Kristen Indonesia (Parkindo), IPKI, Perti and Murba (Setiawan, September 15, 2008).

${ }^{8}$ Romli, Islam Yes, Partai Islam Yes, p. 35, p. 42, and p. 57. 
developmental ethos which made up a cardinal part of his ideology of progress. The number of political parties was drastically cut down following a hardfought 1971 election. In 1973, the New Order regime rationalized party politics by patronizing, on the one hand, the fusion of the Islamic parties of NU, Parmusi, PSII and Perti into a new configuration known until today as the Partai Persatuan Pembangunan (PPP: United Development Party). Nationalist and Christian-based parties: PNI, Partai Katolik, Parkindo, IPKI and Murba, on the other hand, merged to form Partai Demokasi Indonesia (PDI: Democratic Party of Indonesia). Apart from these two official political groupings, the bureaucracy, the army (TNI: Tentera Nasional Indonesia) and a handful of nationalist organizations set up the Golongan Karya (Golkar), a functional organization which effectively played the role of the ruling party despite its official disavowal of its formal status as a political party.

During the early phase of the New Order, Islamic leaders and politicians outside PPP expressed interest in mobilizing together as the Partai Demokratik Islam Indonesia (PDII: Islamic Democratic Party of Indonesia). The attempt to found such an entity was foiled by the New Order leadership for fear that it would cause political instability and locking of horns with the Muslim modernists. Furthermore, the Islamic figures had yet to gain the trust of the state. The New Order regime thus urged them to join ranks with Partai Muslimin Indonesia (Parmusi: Party of Indonesian Muslims). ${ }^{9}$

In 1984, internal bickering erupted between the NU and Muslimin Indonesia factions within PPP. Factional tussles arose over leadership positions, methods of responding to the government policies, use of party symbols, nomination of candidates for the national legislature, and allegations of some leaders' conniving with their counterparts in Partai Komunis. The conflict escalated to such an extent that in its muktamar (national conference) in $1984 \mathrm{NU}$ resolved to return to its Platform of 1926 (Khittah 1926), which restores NU's position as primarily a socio-religious organization that distances itself from political affairs which simply implied ending its formal membership in PPP. As the backbone of PPP, NU felt politically marginalized and groused against what it perceived to be unfair allocation of seats to it in Parliament. The departure of NU from PPP reduced electoral support

${ }^{9}$ Romli, Islam Yes, Partai Islam Yes, p. 59; Dhurorudin Mashad, Akar Konflik Politik Islam di Indonesia (Jakarta: Pustaka Al Kautsar, 2008), p. 263. 
for PPP in the following two PEMILUs of 1987 and 1992, during which it managed to garner only $15.9 \%$ and $17 \%$ of popular votes respectively. In 1997, however, PPP's popular support rose back to $21 \% .10$

The passing of the New Order marked the dawn of a new era of Reformasi which since 1998 had opened the floodgates for incessant demands for political freedom. The archetypal Indonesian way of ordering society via state-orchestrated authoritarian measures had suddenly become untenable. Hundreds of political parties including Islamic ones were established. 41 of the 141 parties which registered to participate in the 1999 PEMILU were purportedly Islamic entities. 17 of the 48 parties which passed the process of selection and verification were Islamic groups. Nonetheless, the figures declined for 2004, when, of the 46 parties that successfully went through the Election Commission's selection and verification exercise, only 7 bore specifically Islamic labels. The experience of political party fragmentation during the Old Order and the New Order was repeated during Reformasi. Despite Islamic parties initially positioning themselves as the mainstay of political reform in the new Indonesia, internal and conflict greatly eroded their overall strength in the three PEMILUs that had taken place since the onset of Reformasi. ${ }^{11}$

${ }^{10}$ Mashad, Akar Konflik Politik Islam di Indonesia, pp. 59, 84.

11 The list of Islamic political parties participating in the 1999 PEMILU is marked by various appellations which can be categorized into, first, large Islamist parties such as Partai Persatuan Pembangunan (PPP: United Development Party), Partai Bulan Bintang (PBB: Crescent and Star Party), Partai Keadilan Sejahtera (PKS: Justice and Prosperity Party), Partai Amanat Nasional (PAN: National Mandate Party) and Partai Kebangkitan Bangsa (PKB: National Awakening Party). Second, relatively small and arguably unsustainable parties such as Partai Ahlussunah Waljamaah (PAS: Sunni Party), Partai Aliansi Kebangkitan Muslim Sunni Indonesia (Alliance of the Awakening Indonesian Sunni Party), Partai Abul Yatama (PAY: Abul Yatama Party), Partai Amanat Masyarakat Madani (PAMM: Civil Society Mandate Party), Partai Politik Tharikat Islam (PPTI: Islamic Tharikat Political Party), Partai Bhakti Muslim (PBM: Muslim Dedication Party), Partai Cinta Damai (PCD: The Peace Loving Party), Partai Demokrasi Islam Republik Indonesia (Indonesian Islamic Democratic Party), Partai Dinamika Umat (People's Dynamics Party), Partai Dua Syahadat (Two Syahadat Party), Partai Era Reformasi Tarbiyah (Educational Reformation Party), Partai Indonesia Baru (PIB: New Indonesian Party), Partai Islam Indonesia (PII: Indonesian Islamic Party), Partai Islam Persatuan Indonesia (United Indonesian Islamic Party), Partai Gerakan Insan Muttaqin Indonesia (Indonesian Movement of Pious People's Party), Partai Ka’bah (Kaaba Party), Partai Kebangkitan Kaum Ahli Sunnah (PAKKAM: The Sunni Awakening Party), Partai Kebangkitan Muslim Indonesia 
Projections from various surveys conducted throughout 2012 have concluded that most Islamic parties suffer from a poor support base. In fact, if a PEMILU were to be called for at the time of the surveys, only two Islamic parties would pass the required 3.5\% electoral threshold as stipulated. Hence, if their existence were to have any impact on the Indonesian populace, the best or rather only option left for them is to synergistically merge. ${ }^{12}$ Such a recourse had evidently been successfully treaded in the early years following independence, when Islamic social organizations joined forces with Masyumi, forming an electoral bloc which garnered up to $50 \%$ of popular support. After many years of subdued existence under the New Order, Islamic parties re-asserted their claims as political stakeholders during Reformasi by mobilizing the Poros Tengah (lit. Middle Axis), which successfully maneuvered the way for Abdurrahman Wahid (Gus Dur) to become the first democratically elected President of Indonesia. But internal conflict and fragmentation were not the only factors contributing to the ebbing of Islamic parties' fortunes. Among other reasons, Muslims' lack of integrity and their parties' inability to offer distinctive programs also accounted for their decline. This article will discuss three important issues. First, we look at the pattern of rupture that characterized the multi-layered inter-relationships among Islamic parties during the period following Reformasi. Second, we broach some of the reasons for that rupture. Third, we delve into political implications arising from the rupture to the parties themselves and also to the Muslim community at large.

(Muslim Awakening Party), Partai Kebangkitan Umat (Ummah Awakening Party), Partai Kesatuan Umat Indonesia (PKUI: United Indonesian People's Party), Partai Kesatuan Wahdatul Ummah (PKWU: The United People's Party), Partai Politik Islam Masyumi (Masyumi Islamic Party), Partai Majawangi, Partai Masyumi Baru (PMB: New Masyumi Party), Partai Nahdlatul Ummah (Nahdlatul Ummah Party), Partai Persatuan (Union Party), Partai Persatuan Islam Indonesia (PPII: United Islamic Political Party), Partai Persatuan Sabilillah (PPS: United Sabilillah Party), Partai Pengamal Thariqat Islam (PPTI: Indonesian Thariqat Practitioners Party), Partai Politik Tharikat Indonesia (PPTI: Indonesian Tharikat Political Party), Partai Solidaritas Sunni Indonesia (SUNNI: Indonesian Sunni Solidarity Party), Partai Syarikat Islam Indonesia (Indonesian Islamic Corporation Party), Partai Umat Islam (PUI: Indonesian Muslim Party), Partai Umat Muslim Indonesia (Indonesian Party of Muslims), and Partai Islam Demokrat (PID: Islamic Democratic Party).

12 “Jika Ingin Bertahan, Partai Islam Sebaiknya Bergabung," Kompas, October 22, 2012. 
In this study, we define 'Islamic political parties' as parties which possess Islamic attributes and use Islamic symbols in showcasing their ideologies and policies, which were established based upon and persistently rely on support from Muslims, and whose trajectories set them on a clearly different course from those pursued by non-Muslim parties. Based on this categorization, we may identify the large Islamic parties, which consist of Partai Persatuan Pembangunan (PPP), Partai Keadilan Sejahtera (PKS), Partai Kebangkitan Bangsa (PKB), Partai Bulan Bintang (PBB), Partai Amanat Nasional (PAN), and Partai Bintang Reformasi (PBR). Beside these major political actors, there are also a multitude of small Islamic parties (partai gurem). ${ }^{13}$ In the Indonesian context, Islamic parties differ from nationalist parties in that unlike the former which categorically struggle for Islamic causes, nationalist parties do not relate their struggle to Islam, but rather to the interests of Indonesian society, notwithstanding the fact that Muslims make up the vast majority of the national population. They also do not depend solely on Muslim constituents, but rather to a more plural constituency in ethno-religious terms, for their political survival and advancement. In many respects, nationalist parties hold to views, stances and attitudes which unambiguously differentiate them from Islamic parties.

13 Our definition draws from the diverse conceptual understandings put forward by Azyumardi Azra (2002), Dhorurotin Mashad (2008) and Lembaga Survei Indonesia (2008), which classify Islamist parties according to persuasion, constituency and extent of domination of Muslim politicians. Azra divides Islamist parties into three categories: parties which avoid using Islam in its program but relies on Muslim constituents, parties which are dominated by Muslim politicians and free from the programs and influence of non-Islamist parties and non-Muslim constituents, for example Golkar, and finally parties that explicitly employ Islam as its main and official agenda; see Azyumardi Azra, Reposisi Hubungan Agama dan Negara: Merajut Kerukunan Antarumat (Jakarta: Kompas, 2002), pp. 90-110. In Akar Konflik Politik Islam di Indonesia (2008), Mashad classifies Islamist parties into "formal" and "substantive" types. Whilst the former formally and unequivocally foregrounds Islam in their symbols and policies, the latter dispenses with such Islamist certitude but still depends on Muslim constituents for the bulk of its support. Substantive Islamist parties, in other words, are inclined to adopt a plural and inclusive character. For Lembaga Survei Indonesia (2008), Kekuatan Elektoral Partai-Partai Islam menjelang Pemilu 2009 (Jakarta, September 2008), an Islamist party is understood as a party which possesses an Islamic-based platform and enjoys a sociological and historic relationship with Islam. 


\section{The Anatomy and Causes of Fragmentation and Conflict among Islamic Political Parties}

Debating the causes of fragmentation and conflict in the convoluted terrain of Islamic party activism can be daunting if one were to be reminded of the fact that no fewer than a hundred political parties claiming to project an Islamic identity were suddenly catapulted into public space upon the launching of Reformasi. Nonetheless, not all protagonists of the many partai gurem were serious in expanding their parties' wings. By and large only politicians from the large Islamic parties became staunch torchbearers for Islamic politics in the new open political arena. These large Islamic parties not only gained indirect support from major Islamic civil society organizations such as Nahdlatul Ulama (NU), Muhammadiyah, Dewan Dakwah Islamiyah dan Gerakan Dakwah Kampus, but they also claim to inherit the mantle of the Old Order's Islamic parties such as Masyumi and Partai Syarikat Islam Indonesia (PSII). In explaining factors leading to the fragmentation and conflict among Islamic political parties, this article borrows the theoretical framework developed by Nazarudin Syamsudin, Zulkifli Hamid and Toto Pribadi. These three scholars are of the opinion that the underlying causes of Islamic fragmentation and conflict can be found in the ideological differences among party members, divergent ways of implementing their respective party programs and leadership competition pitting Islamic leaders against one another whether in the same or different party. ${ }^{14}$ As had transpired under the Old Order, fragmentation of the Islamic camp during the nascent period of Reformasi was greatly conditioned by the different ideological orientations of its protagonists. In spite of the fact that such differences may have only been at the surface rather than substantive level, Islamic leaders in Indonesia still failed to agree on a common platform and method of implementing Islamic precepts which emphasize the values of brotherhood, camaraderie and consensus in their political lives.

Although the Islamic parties differ in name, leadership and management, they share certain common traits such as the symbolic use of the cresecent and the five-pointed star, the kalimah syahadah, the ka'bah, and the phrases 'Ablussunah Waljamaab', 'Allah', and 'Tasbih'. In

\footnotetext{
14 Nazarudin Syamsudin, Zulkifli Hamid and Toto Pribadi, Sistem Politik Indonesia (Jakarta: Karunika, Universitas Terbuka, 1988), pp. 5-6.
} 
addition, they stick to one common principle i.e. Islam or the Islamic religion (dienul Islam), or a combination of maxims and concepts invariably associated with Islam such as Akblakul karimah (good deeds), Al-Quran and Hadiths (traditions of the Prophet Muhammad). Some Islamic parties encourage the inculcation of Islamic values in practical governance, for instance through the formalization of Islamic Law (Syariab), increase in the quality of life and enhanced participation of the Muslim masses in public affairs. These principles are then integrated with the nationalist ethos towards the defence of the Republic of Indonesia. Other general objectives include encouraging the development of a just and prosperous society, advocating that national aims be streamlined with the ambitions of Reformasi, and fostering a democratic political system in line with Pancasila. These parties bank on support from the diverse Muslim communities to achieve their political agendas. ${ }^{15}$

The ideological differences amongst leading figures of Islamic parties are manifested in the polarization of their support base according to doctrinal lines. ${ }^{16} \mathrm{NU}$ elites who embrace traditionalist Islam depend on the NU masses. Parties that claim to inherit Masyumi's legacy rely for support on the modernist Muslim constituency. Yet characteristics of Islamic parties in Reformasi era differ in significant aspects from their predecessors of the 1950s such that it might not be appropriate to regard them as the legitimate successor of their political forerunners. Islamic parties of the 1950s such as Masyumi, among whose ranks include members of both Muhammadiyah and NU, had the establishment of Negara Islam Indonesia (Islamic State of Indonesia) as its cardinal aim, whereas latter-day Islamic parties such as PKB and PAN are open parties which do not include Negara Islam Indonesia as part of their agenda. Even the more exclusive parties such as PBB, PPP and PKS, while lending support to the adoption of Piagam Jakarta (Jakarta Charter), do not explicitly proclaim the intention to establish a Negara Islam Indonesia. ${ }^{17}$

15 Romli, Islam Yes, Partai Islam Yes, p.143; Mashad, Akar Konflik Politik Islam di Indonesia, p. 263.

${ }^{16}$ Mashad, Akar Konflik Politik Islam di Indonesia, pp. 140-145.

17 Fahry Ali (Interview), 'Politik Santri selalu tersubordinasi oleh Kekuasaan', Suara Muhammadiyah, No.11/TH. Ke-93/, June 1-15, 2008. 
Out of seventeen Islamic parties which entered the PEMILU fray in 1999, nine of them, viz. PSII 1905, PSII, PPP, PMB, PII, PBB, PUI, PK and PP, explicitly declared Islam to be their party ideology. However, eight others including PUMI, Partai SUNNI, PNU, PCD, PKU and PAC chose together Pancasila and Islam as a joint-ideology, or expressed preference for some classical Islamic notion or terminology such as Ablussunah Waljamaah as party ideology. ${ }^{18}$ These parties may claim themselves to be Muslim nationalists and enunciate Pancasila as their parties' foundational ideology while at the same time taking Islam as their reference point in religious affairs and political morality. ${ }^{19}$ PAN implicitly adopts Islamic values, for example in enjoining its members to perform good deeds in their daily lives, as the basis for its acculturation program for its rank-and-file members. PAN's emblem, the blue sun, strongly resembles that of Muhammadiyah, the second largest Muslim civil society organization with whom most PAN members are affiliated. This is understandable in view of PAN's reliance on grassroots support from Muhammadiyah. Associated in the minds of many as the political arm of Muhammadiyah, PAN draws its membership from elites in big cities and districts where the major universities, the critical middle class and Muslim modernists are found in abundance, for example Yogyakarta and West Sumatera. ${ }^{20}$

Beside the ideological factor, competition among elites and differences of opinion around questions of policy implementation also contribute to fragmentation and conflict among Islamic political parties. Parties which claim to continue the struggles of Syarikat Islam Indonesia (PSII) and Masyumi and those which were set up by leaders of Nahdlatul Ulama (NU) and PAN are all embroiled in the wrangling. PSII, for instance, split into two groups: PSII 1905 headed by Ohan Sudjana and PSII helmed by Anwar Tjokroaminoto, grandson of HOS Tjokroaminoto, the founder of SI. Both factional leaders not only failed to stem germination of the seeds of conflict which had been sowed way back in 1972, but they were also unsuccessful in consolidating their pragmatic interests within the larger grouping.

\footnotetext{
${ }^{18}$ Fahry Ali, 'Politik Santri selalu tersubordinasi oleh Kekuasaan'.

${ }^{19}$ See for instance AD/ART PAN, article 3.1

${ }^{20}$ Abdul Munir Mulkan, 'Memahami Perilaku Pemilih Muslim,' in Hamid Basyaib and Hamid Abidin (eds), Mengapa Partai Islam Kalab (Jakarta: Alvabet, 1999), p. 126.
} 
Similar factors accounted for fragmentation and conflict among Islamic parties which claim to be the intellectual descendants of Masyumi. Dismally failing to consolidate their respective congregations, leading figures of the Masyumi tradition presided instead over the fragmentation of their bloc into: Partai Bulan Bintang (PBB), Partai Masyumi Baru (PMB), and Partai Persatuan Islam Indonesia ${ }^{21}$ Within the Nahdliyin or the NU bloc, seven parties also emerged out the internal fragmentation and conflict: Partai Kebangkitan Bangsa (PKB), Partai Nahdlatul Ummah (PNU), Partai SUNI, Partai Kebangkitan Ummah (PKU), Partai Persatuan Pembangunan (PPP), Partai Persatuan (PP) dan Partai Bintang Reformasi.22

Inter-factional fragmentation was aggravated by wrangling within a particular party, for example internal conflict within $\mathrm{PKB}$ and within PPP. The first conflict between the Nahdliyin pitted PKB against PPP. This clash was a hangover from the New Order conflict which led to NU's severing relations with PPP. Upon the formation of PKB by NU elites, many NU politicians in PPP including Matori Abdul Djalil and Khofifah Indar Parawangsa promptly transferred their allegiance to PKB. PPP saw this exodus as political treachery. PKB elites, on their part, accused NU politicians who chose to remain with PPP as NU renegades. Abdurrahman Wahid (Gus Dur), founder and then head of PKB's syuro council went to the extent of berating PPP as lacking adequate Islamic knowledge and being pro-status quo. This conflict even led to physical confrontation between sympathizers and supporters of both sides in several districts such as Pekalongan, Jepara and Yogyakarta. ${ }^{23}$

Conflict arising from elite competition and policy differences extended in time to conflicts between PKB and PNU, between PKB and PKU, between PKB and SUNNI and internal conflict within PKB. Conflict between PKB and PNU was the consequence of PKB progenitor Gus Dur's wish that NU established a more open party which installed the principles of Pancasila and Nasionalism as the party ideology. On the other side of the coin, Syukron Makmun, one of the leading figures of the $\mathrm{NU}$ faction propped up by the Ittihadul

\footnotetext{
${ }^{21}$ Ibid., p. 191.

22 Mashad, Akar Konflik Politik Islam di Indonesia, pp. 143-144.

23 Ibid., pp. 198-201.
} 
Mubalighin group, who later emerged as leader of Partai Nahdlatul Ummah (PNU), insisted on a party which showed unflinching loyalty to Islam of the Ablussunah Wal Jamaab variety, as couched in its four recognized legal schools, viz Hanafi, Maliki, Syafii, and Hanbali. ${ }^{24}$

Conflict between PKB and Partai Kebangkitan Ummah (PKU), a former constituent of $\mathrm{PKB}$, was an outgrowth of PKB's adamance in promulgating Pancasila as the party ideology. Dominated by Gus Dur's faction, $\mathrm{PKB}$ officially rejected the formalization of Islamic law as a cornerstone of the Indonesian state. They argued that despite its constitutional niceties, such a formal arrangement would not be able to deliver justice. The opposing faction then formed the splinter group of PKU headed by Yusuf Hasyim and Sholahuddin Wahid. PKU demanded the use of constitutional mechanisms to encourage the adoption of Islamic law as the basis of Indonesia's legal and political system. They assert that the inculcation of Islamic rules and regulations for Muslims was valid and in line with NU's mission. Conflict also arose between factions led by Gus Dur and Abu Hasan, who steered his followers to form the breakaway group of SUNI. The immediate reason behind the quarrel appeared to be related to inter-elite competition during the election for NU's executive leadership at its 1994 Congress in Cipayung in which Abu Hasan was defeated by Gus Dur in a race for the position of Head of NU's Executive Council. ${ }^{25}$

Differences of views pertaining to internal policy implementation also flared up into rupture within the large PKB family. The first conflict pitted Gus Dur, Head of the Dewan Syuro (Advisory Council) against Matori Abdul Djalil, head of the Dewan Tanfidziah (Executive Council). Gus Dur had prohibited Matori from attending parliamenttary sessions on the basis that it went against party policy. Matori retaliated by brusquely opposing the presidential decree issued by Gus Dur, who then maneuvered the abrupt replacement of Matori as head of Dewan Tanfidziah with Alwi Shihab. The internal fighting polarized PKB into two opposing factions: PKB Batutulis led by Matori and PKB Kuningan helmed by Gus Dur and Alwi Shihab.

The second internal conflict transpired when the Gus DurMuhaimin Iskandar and Alwi Shihab-Syaifullah Yusuf factions locked

\footnotetext{
${ }^{24}$ Bahrul Ulum, "Bodohnya NU”, apa "NU Dibodohi ?? (Yogyakarta: Ar-Ruzz, 2002), pp. 135-136.

25 Ibid.
} 
horns with each other. Alwi Shihab was then Coordinating Minister for People's Well-being (Menteri Koordinator Kesejahteraan Rakyat) while Syaifullah Yusuf held the post of State Minister of Underdeveloped Districts (Menteri Negara Pembangunan Daerah Tertinggal) in the cabinet of President Sushilo Bambang Yudhoyono (SBY). ${ }^{26}$ Gus Dur's decision, taken in his capacity of Head of the Dewan Syuro, to sack Alwi Shihab and Syaifullah Yusuf outside of the official party mechanism triggered the quarrel. Gus Dur accused the two politicians of neglecting their responsibilities as the party's Chief Executive and Secretary General respectively. As a consequence, PKB split into opposing Gus Dur-Muhaimin and Alwi Shihab-Syaifullah Yusuf factions. Thereafter Alwi Shihab and Syaifullah Yusuf appointed Abdurrahman Chudlori, an NU cleric from Magelang Central Java to the position of Head of the Dewan Syuro and promoted Chairul Anam as Head of the Executive Council. ${ }^{27}$

The Alwi-Syaifullah faction received support from eleven Kyai Langitan (spiritual leaders) who rejected the Congress for allegedly flouting party regulations. Contrary to expectations, 29 regional representatives nominated Gus Dur yet again for the post of Head of Dewan Syuro. The Alwi-Syaifullah faction heaped blame on party elites for deposing them, as they claimed to have acquired the rightful mandate of leadership within the party as a result of having been lawfully elected during the Extraordinary Congress in Yogyakarta on 17-19 January 2002.28 The conflict eventually ended with the withdrawal of Alwi and Syaifullah from PKB. Alwi Shihab then sought to establish the Partai Kebangkitan Nahdlatul Ulama (PKNU), while Syaifullah Yusuf moved to PPP. ${ }^{29}$

The third conflict saw a rift develop between ertswile allies, namely Gus Dur and Muhaimin Iskandar, also a former Head of the Executive Council. Gus Dur fired Muhaimin Iskandar without going through

\footnotetext{
26 "PKB, Berpartai di Tengah Konflik", http://www.hupelita.com/baca.php?id=55$\underline{400}$, accessed on July 10, 2010.

${ }^{27}$ Kamarudin, Konflik Internal PKB (Jakarta: Akses Publishing, 2008), pp. 2-3.

${ }^{28}$ H. Anton Djawamaku, "Perpecahan Partai Politik, Pemberantasan Korupsi dan Berbagai Masalah Politik Lainnya," Analisis CSIS, Vol. 34, No. 2 (June 2005), pp. 123125.

${ }^{29}$ Kamarudin, Konflik Internal PKB, pp. 2-3, and p. 44.
} 
proper party channels, supplanting him with Ali Masykur Musa. ${ }^{30}$ According to Gus Dur's version of events, Muhaimin had attempted to oust Gus Dur from the leadership of the Dewan Syuro and install instead Hasyim Muzadi, NU chief executive, in his place. Gus Dur also accused Muhaimin of cooperating with President SBY. As evidence of his allegations, Gus Dur referred to SBY's decision to appoint Muhaimin's nominee, Lukman Edy, as Minister of Underdeveloped Districts, thus repudiating Gus Dur's proposed candidate Sigit Haryo Wibisono. ${ }^{31}$ Protesting against Muhaimin's dismissal, members of his faction brought the matter to the courts which pronounced that the sacking was invalid. Based on the judicial verdict, Muhaimin and Lukman Edy continued to lead PKB in their official capacities. ${ }^{32}$

Table 1: Chronology of Internal Conflict within PKB $^{33}$

\begin{tabular}{|c|c|c|c|c|}
\hline Phase & Conflicting Parties & Period & Case & Consequences \\
\hline 1 & $\begin{array}{l}\text { Matori Abdul Djalil } \\
\text { (PKB Batutulis) vs } \\
\text { Gus Dur Alwi } \\
\text { Shihab (PKB } \\
\text { Kuningan) }\end{array}$ & $2001-2002$ & $\begin{array}{l}\text { Head of Dewan } \\
\text { Syuro Gus Dur } \\
\text { sacks Head of Party } \\
\text { Executive Matori } \\
\text { Abdul Djalil }\end{array}$ & $\begin{array}{l}\text { Matori leaves PKB } \\
\text { Kuningan and } \\
\text { forms PEKADE }\end{array}$ \\
\hline 2 & $\begin{array}{l}\text { Abdurrahman } \\
\text { Wahid-Muhaimin } \\
\text { Iskandar vs Alwi } \\
\text { Shihab-Saifullah } \\
\text { Yusuf }\end{array}$ & 2004-2007 & $\begin{array}{l}\text { Without } \\
\text { congressional } \\
\text { approval, Dewan } \\
\text { Syuro dismisses Alwi } \\
\text { Shihab as Head of } \\
\text { Party Executive and } \\
\text { Syaifullah Yusuf as } \\
\text { Secretary-General, } \\
\text { arising from their } \\
\text { appointments as }\end{array}$ & $\begin{array}{l}\text { Alwi Shihab and } \\
\text { Syaifullah Yusuf } \\
\text { resigns from PKB. } \\
\text { Alwi Shihab } \\
\text { establishes PKNU } \\
\text { and Syaifullah joins } \\
\text { PPP }\end{array}$ \\
\hline
\end{tabular}

30 Dwi Riyanto Agustiar, "PKB Kubu Muhaimin Segera Bawa Hasil Muktamar ke Departemen Hukum”, May 4, 2008, www.tempointeraktif.com $/ \mathrm{hg} / \mathrm{nasional} / 2008 /$ 05/04/brk,20080504-122433.id.html, accessed on July 10, 2010.

31 Asrori S. Karni, "Partai Kebangkitan Bangsa: Manuver Gus Dur Menggoyang Muhaimin”, Gatra, no. 36, July 25, 2007, http://www.gatra.com/2007-07-25/artikel.php?id=106372, accessed on March 4, 2009.

32 “Departemen Hukum Sahkan Kubu Muhaimin”, Tempo, June 25, 2008, http://hukumham.info/index.php?option $=$ com content\&task $=$ view\&id $=1073 \& I t e m i d$, accessed on March 4, 2009.

${ }^{33}$ Kamarudin, Konflik Internal PKB. 


\begin{tabular}{|c|c|c|c|c|}
\hline Phase & Conflicting Parties & Period & Case & Consequences \\
\hline & & & $\begin{array}{l}\text { members of SBY's } \\
\text { cabinet }\end{array}$ & \\
\hline 3 & $\begin{array}{l}\text { Muhaimin Iskandar- } \\
\text { Lukman Edy vs Gus } \\
\text { Dur Ali Masykur } \\
\text { Musa-Yenny Wahid }\end{array}$ & 2008 & $\begin{array}{l}\text { Dewan Syuro ousts } \\
\text { Muhaimin Iskandar } \\
\text { as Head of Party } \\
\text { Executive. Gus Dur } \\
\text { accuses Muhaimin } \\
\text { of attempting to } \\
\text { depose him from his } \\
\text { position as Head of } \\
\text { Dewan Syuro }\end{array}$ & $\begin{array}{l}\text { Muhaimin brings } \\
\text { this case to the } \\
\text { judiciary and won. } \\
\text { He therefore } \\
\text { continues in his } \\
\text { position as Head of } \\
\text { Party Executive. }\end{array}$ \\
\hline
\end{tabular}

Divergence of views on policy implementation can be explained at both individual and institutional levels. At the individual level, Gus Dur's uniquely unrelenting disposition was the overriding factor. At the institutional level, the management of $\mathrm{PKB}$, as a new political organization, was found lacking in modern political culture.34. PKB failed to circumscribe Gus Dur's personal influence which often transgressed internal party rules. Difficulties persistently cropped up because Gus Dur had from its outset wielded a dominant say over PKB's domestic affairs. Although the conflict was eventually settled through judicial proceedings, it most probably contributed significantly to the decline in popular support for PKB in the three PEMILUs of Reformasi era.

In 2004, a bitter leadership struggle drove a wedge within the upper echelons of PPP's internal structure. This occurred when a wellknown preacher, Zainuddin MZ, along with his compatriots among PPP leaders left PPP to form Partai Bintang Reformasi (PBR). Regarding PBR's ideological orientation as no different from the true precepts of PPP, Zainuddin expressed disappointment at PPP and other Islamic parties for failing to fulfill his hopes. ${ }^{35}$ Conflict within PPP was further externalized when the MI-Parmusi factions and several NU politicians who remained in PPP were at loggerheads over the distribution of seats in Parliament. NU politicians in PPP thought that they had received a less than fair deal since having their allocation

34 Bahtiar Effendi, 'Gus Dur tidak salah', http://www.inilah.com/, November 23. 2009, accessed on March 4, 2009.

35 Irsyad Zamjani, Sekularisasi Setengah Hati (Jakarta: Dian Rakyat, 2009), p. 223. 
cut down during the PEMILU of $1977 .{ }^{36}$ In another drama, Head of PPP Suryadarma Ali removed Irgan Chairul Mahfuds from the party's Department of Secretary-General. Ali also refused to support candidates from among PPP home-grown cadres for district elections in East Java XI and West Java XI. The recurring conflicts revolving around the question of candidacies for parliament demonstrated the unduly dominant influence that traditional leaders possessed over party procedures. In addition, some of them unabashedly brought along with them a slew of oligarchic and corrupt practices which flouted fundamental political ethics. ${ }^{37}$

Internal wrangling also affected Partai Amanat Nasional (PAN) after the PEMILU of 2004. Frustrated PAN members, who were overwhelmingly also members of Muhammadiyah as the main constituent group of PAN, founded the Partai Matahari Bangsa (PMB). They argued that PAN had failed to further the interests of Muhammadiyah despite the fact that a large majority of PAN leaders had originated from Muhammadiyah. The rupture led to the scattering of politically-inclined Muhammadiyah members into several different political parties. ${ }^{38}$ However, internal conflict within PAN had no significant impact on popular support for PAN. Its popular vote tally of $6.01 \%$ during the PEMILU of 2009 was only a slight decrease from what it had registered in 2004. The PMB experimentation may be deemed to have failed if assessed from the dismal $0.4 \%$ of popular votes that it commanded, thus failing to even reach the electoral threshold. Meanwhile, other more sustainable Islamic parties were also unsuccessful in garnering higher support from the masses. Smaller Islamist parties such as PBB found it difficult to defend its measure of popular support mustered in 2004. The anatomy of fragmentation and conflict of Islamic political parties can be gleaned from the figure 1.

\footnotetext{
36 Romli, Islam Yes, Partai Islam Yes, pp. 72-74.

37 R Ferdian Andi, 'Kisruh di PPP? Sudah Tradisi!', http://www.inilah.com/berita/pemilu-2009/2008/, accessed on March 4, 2009.

38 Idris Hemay, 'Pertarungan Parpol Islam 2009', http://www.csrc.or.id/artikel, accessed on March 4, 2009.
} 
Figure 1: The Anatomy of Fragmentation and Conflict of Islamic Political Parties in the Post-Reformasi Era

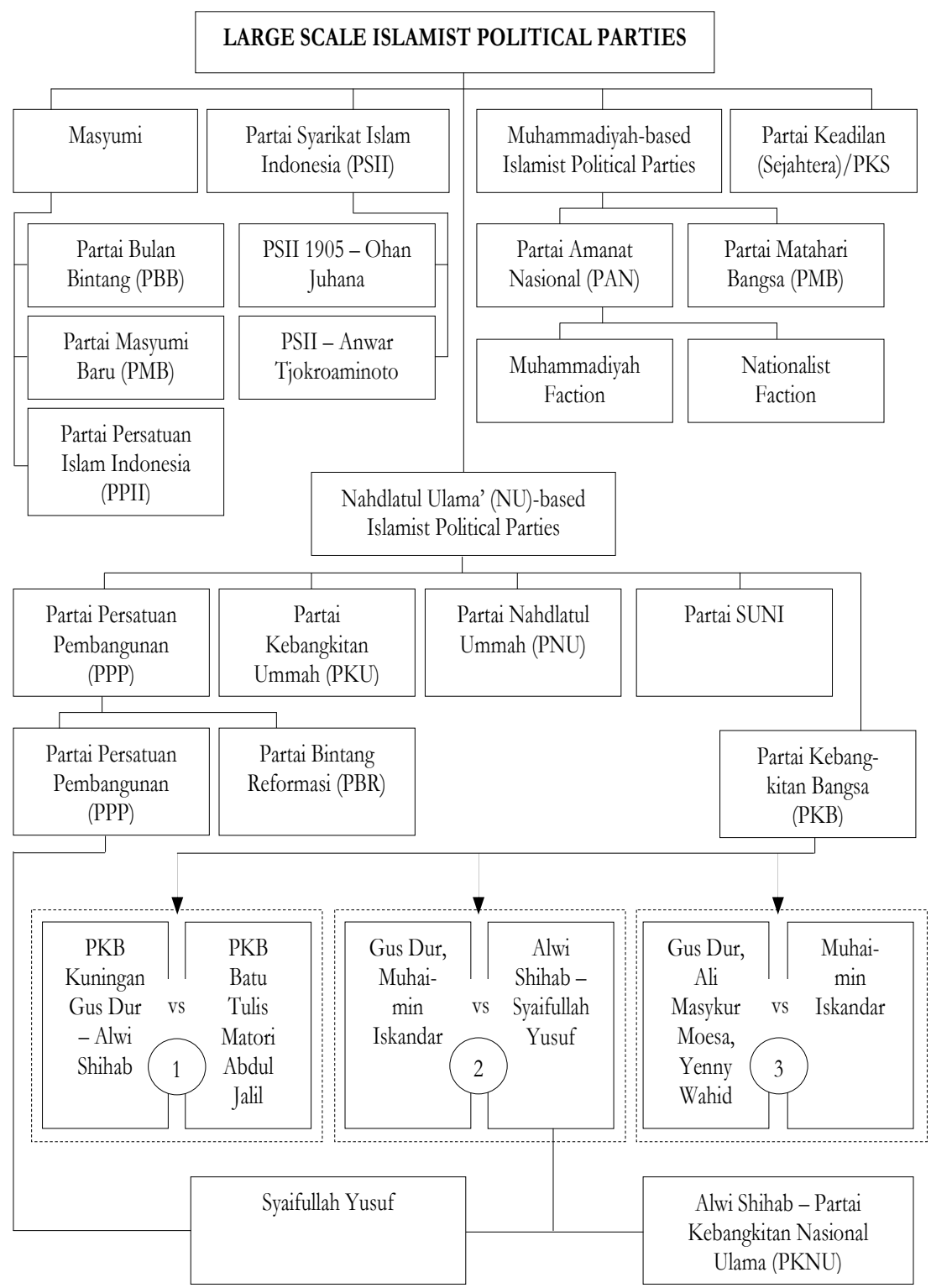




\section{Implications}

The fragmentation and conflict that beleaguered Islamic parties had contributed to the dispersal of Muslim votes and shrinking of the voice of Islamic parties. Muslim constituencies were inclined to distance themselves from the Islamic parties when these parties failed in both distinguishing themselves from secular parties and solving their internal crises, whether inter-party or intra-party. ${ }^{39}$ Muslim failure to vote as a unified bloc rendered unsuccessful every attempt by Islamic parties to become the majority voice in Parliament. Fragmentation at the upper echelons of party leadership filters down to the grassroots level as defeated leadership candidates resort to founding new parties, hence further complicating the already muddled scenario. Ambitious but quixotic, such aspirants to political power effectively stifled hopes for better synergy and coordination among Islamic parties. To the general public, a prevailing negative impression of Islamic parties has become the norm. ${ }^{40}$

Table 2 shows the proportion of popular votes gained and parliamentary seats won by Islamic parties during the three PEMILUs in Reformasi era. After ten years of Reformasi (1999-2009), the figures for Islamic parties show a marked drop, except in the case of PKS.

Table 2: Percentages of Popular Votes and Parliamentary Seats Mustered by Islamic Parties during the Three Post-Reformasi PEMILUs (1999, 2004, 2009)

\begin{tabular}{lllllllll}
\hline $\begin{array}{l}\text { Islamic } \\
\text { Political } \\
\text { Parties }\end{array}$ & $\begin{array}{l}1999 \\
\text { Votes }\end{array}$ & $\begin{array}{l}1999 \\
\text { Seats }\end{array}$ & $\begin{array}{l}2004 \\
\text { Votes }\end{array}$ & $\begin{array}{l}2004 \\
\text { Seats }\end{array}$ & $\begin{array}{l}\text { Increase } \\
\text { Decrease } \\
(+)\end{array}$ & $\begin{array}{l}\text { 2009 } \\
\text { Votes }\end{array}$ & $\begin{array}{l}\text { 2009 } \\
\text { Seats }\end{array}$ & $\begin{array}{l}\text { Increase } \\
\text { Decrease } \\
(+)\end{array}$ \\
\hline PPP & $10.7 \%$ & 58 & $8.15 \%$ & 58 & $-2.55 \%$ & $5.3 \%$ & 37 & $-2.85 \%$ \\
PKB & $12.6 \%$ & 52 & $10.57 \%$ & 52 & -2.03 & $4.94 \%$ & 27 & $-5.63 \%$ \\
PAN & $7.12 \%$ & 33 & $6.44 \%$ & 53 & $-0.68 \%$ & $6.01 \%$ & 45 & $-0.43 \%$ \\
PBB & $1.94 \%$ & 13 & $2.62 \%$ & 11 & $+0.68 \%$ & $1.78 \%$ & $n / a$ & $-0.84 \%$ \\
PK(S) & $1.36 \%$ & 7 & $7.4 \%$ & 45 & $+6.04 \%$ & $7.88 \%$ & 57 & $+0.48 \%$ \\
PNU & $0.64 \%$ & 5 & $n / a$ & $n / a$ & $n / a$ & $n / a$ & $n / a$ & \\
PKNU & $\mathrm{n} / \mathrm{a}$ & $\mathrm{n} / \mathrm{a}$ & $\mathrm{n} / \mathrm{a}$ & $\mathrm{n} / \mathrm{a}$ & $\mathrm{n} / \mathrm{a}$ & $1.47 \%$ & $\mathrm{n} / \mathrm{a}$ & \\
\hline
\end{tabular}

39 Muhammad Azhar, Posmodernisme Muhammadiyah, (Yogyakarta, Suara Muhammadiyah, 2005), p. 96.

40 S. Kirbiantoro and Dody Rudianto, Pergulatan ideologi Partai Politik di Ideologi Partai Politik di Indonesia: Nasionalisme, Islamisme, Komunisme, Militerisme JJakarta: Inti Media Publisher, 2005), pp. 52-54. 


\begin{tabular}{lllllllll}
\hline PBR & $\mathrm{n} / \mathrm{a}$ & $\mathrm{n} / \mathrm{a}$ & $2.44 \%$ & 13 & $\mathrm{n} / \mathrm{a}$ & $1.21 \%$ & $\mathrm{n} / \mathrm{a}$ & $-1.23 \%$ \\
PPNUI & $\mathrm{n} / \mathrm{a}$ & $\mathrm{n} / \mathrm{a}$ & $\mathrm{n} / \mathrm{a}$ & $\mathrm{n} / \mathrm{a}$ & $\mathrm{n} / \mathrm{a}$ & $0.14 \%$ & $\mathrm{a} / \mathrm{a}$ & \\
PMB & $\mathrm{n} / \mathrm{a}$ & $\mathrm{n} / \mathrm{a}$ & $\mathrm{n} / \mathrm{a}$ & $\mathrm{n} / \mathrm{a}$ & $\mathrm{n} / \mathrm{a}$ & $0.4 \%$ & $\mathrm{n} / \mathrm{a}$ & \\
PSI & $\mathrm{n} / \mathrm{a}$ & $\mathrm{n} / \mathrm{a}$ & $\mathrm{n} / \mathrm{a}$ & $\mathrm{n} / \mathrm{a}$ & $\mathrm{n} / \mathrm{a}$ & $0.14 \%$ & $\mathrm{n} / \mathrm{a}$ & \\
\hline
\end{tabular}

In the three PEMILUs of 1999, 2004 and 2009, Islamic parties never formed the majority bloc in Parliament. As compared with the corresponding figures for nationalist parties, those of Islamic parties showed a clearly declining trend. Figure 2 and 3 depict Islamic parties as consistently managing to gain less than $40 \%$ and $43 \%$ of popular votes and parliamentary seats respectively. These statistics serve to prove that more than $50 \%$ of Muslim voters constantly support nationalist parties in successive PEMILUs, notwithstanding the fact that Muslims make up about $90 \%$ of Indonesia's population and electorate.

Figure 2: Comparison of Popular Votes for Islamic Parties with Popular Votes for Nationalist Parties in the Post-Reformasi Era (1999, 2004, 2009)

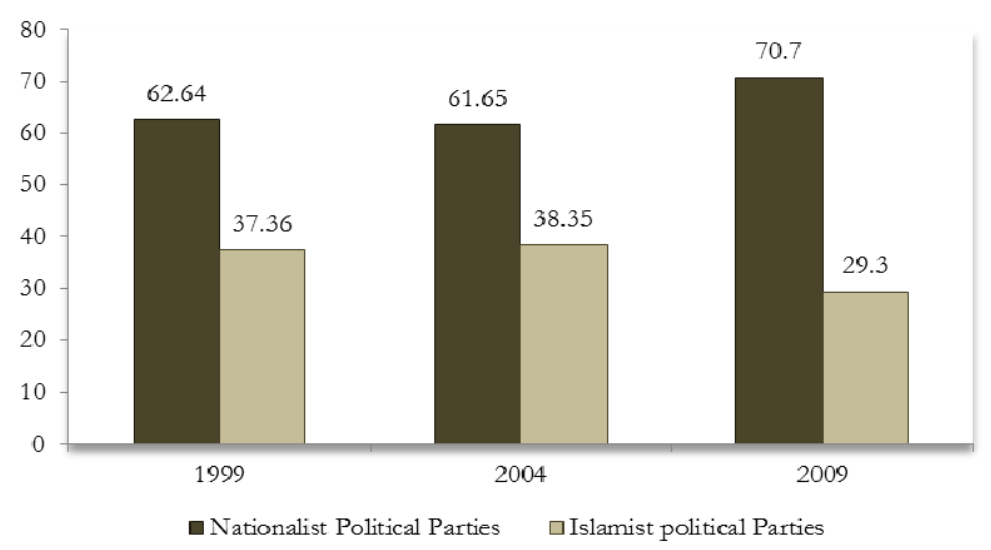


Figure 3: Comparison of Parliamentary Seats of Islamic Parties with Parliamentary Seats of Nationalist Parties in the Post-Reformasi Era $(1999,2004,2009)$

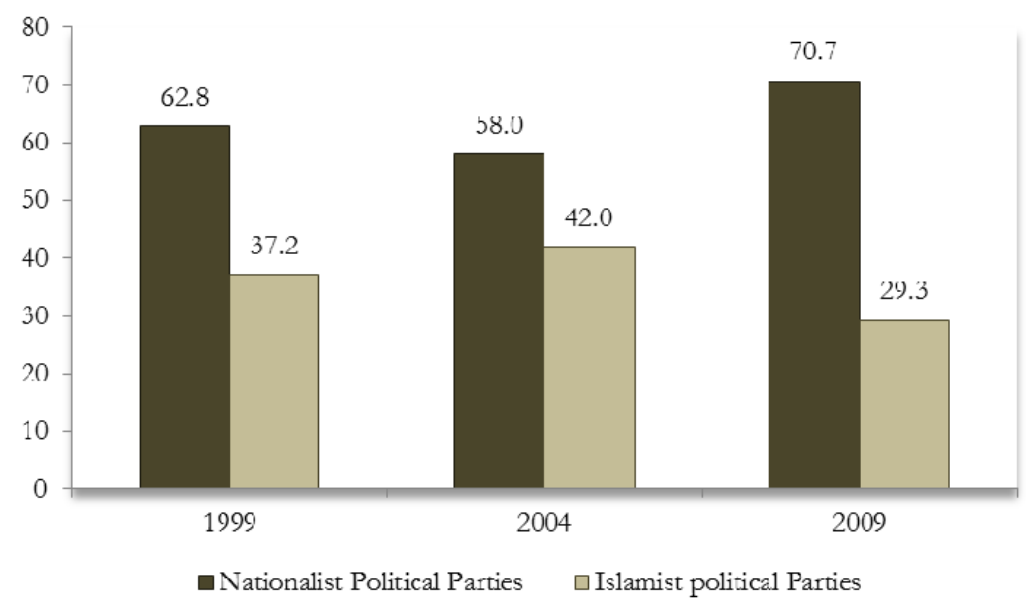

Admittedly, it can be argued that the failure to solve internal conflict was not the sole factor causing stagnation and later decline of support for the Islamic parties throughout the Reformasi period. Other explanations include, first, the majority of Indonesians do not see many differences between the conduct of members of Islamic parties and the behavior of members of nationalist parties, including in the breach of Islamic moral codes. Those identified in the public minds as Islamic politicians are not immune to being implicated in numerous corruption allegations and sex scandals. Their demeanor has been arguably far removed from what the public expects of them as torchbearers of Islam. Their political antics and liberal use of Islamic emblems are thus widely interpreted as being tailored toward selfish political interests. ${ }^{41}$ The following table 3 enumerates Islamic politicians who have been implicated in graft-related scandals.

41 "Perlu Teologi Politik Baru", Suara Mubammadiyah, No 10/TH. Ke 94, May 16-31, 2009. 
Table 3: List of Islamic Politicians Alleged to have been Involved in Corruption $^{42}$

\begin{tabular}{|c|c|c|}
\hline Politician & Political Party & Remarks \\
\hline $\begin{array}{l}\text { Nor Adenan } \\
\text { Razak }\end{array}$ & $\begin{array}{l}\text { PAN / } \\
\text { member of the } \\
\text { commission } \\
\text { VIII }\end{array}$ & $\begin{array}{l}\text { Alleged to have received } 1.52 \text { billion } \\
\text { rupiah from Badan Pengawas Tenaga } \\
\text { Nuklir (BAPETEN: Nuclear } \\
\text { Monitoring Body) for agreeing to } \\
\text { BAPETEN's proposal for extra funds } \\
\text { originating from APBN } 2004 \text {. }\end{array}$ \\
\hline $\begin{array}{l}\text { Yusuf Emir } \\
\text { Faisal }\end{array}$ & PKB & $\begin{array}{l}\text { Alleged to have received } 8 \text { billions } \\
\text { rupiah in the case of the alienation of a } \\
600 \text {-hectare forest reserve in south } \\
\text { Sumatera. Money from the land sale } \\
\text { was later transferred partly to PKB. }\end{array}$ \\
\hline $\begin{array}{l}\text { Al Amin } \\
\text { Nasution }\end{array}$ & PPP & $\begin{array}{l}\text { Alleged to have received } 291 \text { million } \\
\text { rupiah from the alienation of a forest } \\
\text { reserve in Bintan Bunyu, Riau, for the } \\
\text { purpose of urban expansion schemes in } \\
\text { Bintan region. }\end{array}$ \\
\hline Bulyan Royan & $\begin{array}{l}\text { Partai Bintang } \\
\text { Reformasi } \\
\text { (PBR) }\end{array}$ & $\begin{array}{l}\text { Alleged to have received commission } \\
\text { payments amounting to } 8 \% \text { ( } 1.43 \text { billion } \\
\text { rupiah) from Binan Mina Karya } \\
\text { Perkasa, a supplier for the Ministry of } \\
\text { Communications. Acting in cahoots } \\
\text { with other party members, he was said } \\
\text { to have ensured that the company } \\
\text { secure the tender of purchasing } 20 \\
\text { vessels of the value of IDR } 118 \text { billion. } \\
\text { In receiving the commission, he was } \\
\text { purportedly acting on behalf of a } \\
\text { parliamentary committee. }\end{array}$ \\
\hline
\end{tabular}

42 Republika, February 29, 2008; Tempo, March 2008; April 2008; July 2008; July 2008; August 2008. 


\begin{tabular}{|c|c|c|}
\hline Politician & Political Party & Remarks \\
\hline $\begin{array}{l}\text { Yusril Ihza } \\
\text { Mahendra }\end{array}$ & $\begin{array}{l}\text { PBB / Former } \\
\text { Minister of } \\
\text { Law and } \\
\text { Human Rights }\end{array}$ & $\begin{array}{l}\text { Alleged to have received pecuniary } \\
\text { rewards from PT Sarana Rekatama } \\
\text { Dinamika, a company which he pin- } \\
\text { pointed, without going through the } \\
\text { tender process, to operate an } \\
\text { administrative online system at the } \\
\text { Ministry of Law and Human Rights. } \\
\text { The online system was designed to } \\
\text { facilitate the registration of private firms } \\
\text { with the Ministry. PT Sarana Rekatama } \\
\text { Dinamika was thought to have allotted } \\
\text { 10\% of the project's total worth for } \\
\text { underhand distribution to employees } \\
\text { and high-ranking officials of the } \\
\text { Ministry. }\end{array}$ \\
\hline $\begin{array}{l}\text { Artalita Suryani } \\
\text { (Ayin) }\end{array}$ & $\begin{array}{l}\text { Treasurer of } \\
\text { PKB }\end{array}$ & $\begin{array}{l}\text { Alleged to have given monetary } \\
\text { incentives to the value of } 6.1 \text { billion } \\
\text { rupiah to the legal bureau of Urip Tri } \\
\text { Gunawan, which handled the } \\
\text { corruption case of Syamsul Nursalim, } \\
\text { proprietor of Bank Dagang Indonesia } \\
\text { and a friend of Artalita. }\end{array}$ \\
\hline $\begin{array}{l}\text { Waode } \\
\text { Nurhayati }\end{array}$ & PAN politician & $\begin{array}{l}\text { Alleged to have received a bribe of IDR } \\
6 \text { billion for his role in allocating } \\
\text { infrasuctural funds to the regions of } \\
\text { Aceh Besa, Pidie Jaya and Bener Meriah } \\
\text { in Nangroe Aceh Darussalam Province. }\end{array}$ \\
\hline Luthfi Hasan & Former & Together with his close friend Ahmad \\
\hline Ishak & $\begin{array}{l}\text { President of } \\
\text { PKS }\end{array}$ & $\begin{array}{l}\text { Fathanah, he was alleged to have } \\
\text { received a IDR1 billion downpayment } \\
\text { of a bribe totalling IDR } 40 \text { billion, which } \\
\text { PT Indoguna promised to them for } \\
\text { mediating on behalf of the company in } \\
\text { its bid for the licence to import beef. }\end{array}$ \\
\hline
\end{tabular}

Second, Islamic parties lack a clear and consistent direction in their furtherance of party ideology. Islamic parties are widely seen by the Muslim masses as exploiting Islamic symbols for political gain. Unfortunately, such manipulative commodification of religion no longer attracts a large number of Muslim constituents, who prefer instead kesejabteraan (welfare) programs offered by civil society organizations. 
Third, leaders of Islamic parties have by and large conflated between theological and sociological interpretations of political variables. Theologically, they adopt a utopian vision of Islam as a perfect religion with infallible precepts in the political ordering of society. Yet, they are wont to deny the reality that a sustainable hold on power requires broad-based public support. Hence, they sociologically misinterpret that the Muslim society will, in their position as the majority population, necessarily mobilize its members in support of Islamic-based parties. A lot of Islamic politicians take for granted the exigency to make an effort to "convert" their potential Muslim clientele to their policies and causes. Trapped in a normative discourse, Islamic parties become less than sensitive toward the needs of Muslim contituents who demand realistic, contextual and down-to-earth policies with regard to their quotidian interests. These parties have mostly failed to modernize their structures and culture in line with the opening of political space, with liberalizing trends, professional management methods and strategic communications in mundane affairs swiftly following in tandem. ${ }^{43}$

Fourth, many constituents of modernist Muslims blamed the poor performance of Islamic parties and the break down of the Middle Axis on Gus Dur. Islamic parties suffered loss of credibility during Gus Dur's presidency for two reasons. The first is his Israel-friendly foreign policy. Liberal and tolerant as Indonesian Muslims seem to be, the Zionist state's position as the nemesis of Muslims has been powerfully in their minds for generations. ${ }^{44}$ The second is that the Islamic parties, especially those of Masyumi and Muhammadiyah-based parties, also lacked the will to stem the tide of Gus Dur's controversial political maneuvers and poor political as well as administrative performance. In turn, his administration failed to eradicate corruption and hamper economic recovery which is the main raison d'etre of Reformasi. From the Islamic political perspective, it destroys political consensus that hitherto existed especially among supportive Islamic political forces. ${ }^{45}$

\footnotetext{
43 Ahmad Norma Pemata, "Kegagalan Partai Islam", Suara Mubammadiyab; Shohifah, Suara Mubammadiyah, http://suara muhammadiyah.com/2010/?p=593, accessed March 4, 2009.

${ }^{44}$ Mashad, Akar Konflik Politik Islam di Indonesia, p. 275.

45 Azra, Reposisi Hubungan Agama dan Negara, pp. 60-67.
} 


\section{The Fragmentation of Islamic Political Parties in the Presi- dential Election}

In the early years of Reformasi, Islamic political parties had established themselves as a political force to be reckoned with. In 1999, when the President was chosen in Parliament, Islamic parties, mobilized chiefly by Amien Rais of PAN, formed the Poros Tengah (Middle Axis). This coalition created majority in the parliament but it was fragile because it was based on short-terms pragmatic causes. Bolstered by the Golkar party, which was the second largest party after 1999 election, Poros Tengah successfully carried through Gus Dur's candidature for presidency, beating his rival Megawati Soekarno Putri from the nationalist PDI Perjuangan (PDI-P), despite PDI-P garnering the largest number of popular votes in the 1999 PEMILU. Poros Tengah had then played the intermediate role of moderating between the proGolkar Poros Habibie perceived as carrying the New Order legacy, and Poros Megawati propped up by nationalists mainly from PDI-P. Following the majority of parliamentarians' rejection of President Habibie's responsibility speech (pidato pertanggungjawaban) and and the lingering image of Golkar as the political tool of Suharto's authoritarian New Order Regime, Akbar Tanjung as Golkar's General Head (Ketua Umum) hesitated on renominating Habibie for the presidency and aligned instead with Poros Tengah. Apparently this alliance came with heavy price which put heavy burden on Abdurrahman Wahid's administration. Akbar Tanjung's capricious political attitude led to factionalization within Golkar between proHabibie and pro-Akbar Tanjung elements.

Nevertheless, within the period of two years, symptoms of conflict began to show among leading figures of Poros Tengah, pitting especially Gus Dur against Amien Rais, Akbar Tanjung and others. The political infighting brought about the downfall of Gus Dur from the presidency in 2001, after which Megawati automatically ascended to the reins of the power structure as Vice President (Wakil Presiden) whose mainstay of support was Poros Tengah. Ironically, Megawati was previously identified as the leading figure of the nationalist axis which was antagonistic toward Poros Tengah. With the utter disappointment of protagonists of Poros Tengah with Gus Dur, excuses to oust him from presidency were easily fabricated. Gus Dur was alleged to have involved in corruption scandal from National Logistic Bureau (Bulog) infamously known as "Bulog-gate", in the imbroglio of the Sultan of 
Brunei's financial aid known as "Brunei-gate", and in his personal lobbying for the disgraced Tommy Suharto, son of former President Soeharto found guilty of corruption.

In the presidential election of 2004, the strength of Islamic parties was fragmented into five camps, each backing a different presidential candidate with different backgrounds combining nationalist and Islamic persuasions. Islamic parties nominated candidates for both President and Vice President in pairs with nationalist candidates. For example, presidential candidate Megawati Sukarno Putri, as a nationalist figure and General Head of PDI-P paired with vice president candidate Hasyim Muzadi, the distinguished head of Nahdlatul Ulama. Presidential candidate Amien Rais, as leader of the Islamic party PAN and former General Head of Muhammadiyah (PAN-Muhammadiyah) paired with Siswono Yudhohusodo, a former GMNI (Nationalist Student Movement) head and Golkar figure well known for his nationalist leaning. Presidential aspirant Hamzah Haz, incumbent vice President and Head of the Islamic PPP paired with a retired TNI Lieutenant General Agum Gumelar of the nationalist faction. Susilo Bambang Yudhoyono (SBY), the nationalist presidential candidate who had pioneered the splinter Partai Demokrat, chose Jusuf Kalla, a Golkar figure with a background of activist experience in HMI and NU, as his vice President running mate. The SBY-Jusuf Kalla pair eventually won the first-ever direct elections for President and Presidential Representative for the term 2004-2009.

The formation of such ideologically hybrid coalitions involving both nationalist and Muslim politicians and the decline in support for Islamic political parties point toward a certain amount of "deideologization", "desacralization" and perhaps even secularization on their part. ${ }^{46}$ By "de-ideologization" and "desacralization", we mean a process where Islamic politicians no longer rely on Islam as a 'sacred' doctrine on whose basis political decisions and political moves are made and considered. Pragmatic and rational considerations appear to have gained upper hand in their shceme of things. "De-ideologization" often goes hand in hand with secularization, although not necessarily. Throughout Reformasi, it is plausible to argue that Islamic parties underwent secularization to certain degree. ${ }^{47} \mathrm{By}$ "secularization" as a

\footnotetext{
${ }^{46}$ Mashad, Akar Konflik Politik Islam di Indonesia, p. 282.

${ }^{47}$ Ibid., pp. 143-4.
} 
generic term, we mean the use of secular or rational criteria, replacing religious and metaphysical doctrines and emblems in the process of decision-making, in both thought and action. ${ }^{48}$ In the Indonesian political context, secularization denotes a process in which religious symbols or doctrines no longer command a magnetic effect for Islamic parties in attracting the Muslim electorate, for whom religious factors are not accorded priority in making political decisions.

Prior to the presidential election of 2009, some Muslim personalities toyed with the idea of formulating a breakaway Poros Tengah II. Din Syamsudin, the Muhammadiyah head, was among its advocates. Yet, actualization of the idea stalled on account of the many criticisms received and the doubts raised as to its viability. Sceptics disputed the feasibility of coalition politics and raised manifold problems concerning lack of support and finance. The PEMILU of 2009 demonstrated paradoxes governing relationships between Islamic parties and Islamic civil society organizations. Whereas Islamic political parties backed the SBY-Budiono partnership, Muhammadiyah and NU implicitly threw their support behind the Jusuf Kalla-Wiranto duo. As the results turned out, the SBY-Budiono won, while the MegawatiPrabowo combination emerged second, leaving the Jusuf KallaWiranto team in third place. This pathetic outcome should have driven the message to leaders of the Islamic parties that they were far removed from the grassroots aspirations of their purported Muslim constituents. They need to urgently assess their priorities and return to their socio-cultural foundations while at the same time strengthening human resource development among rank-and-file members using modern management techniques. ${ }^{49}$

\section{Conclusion}

There is striking resemblance between the anatonomy of fragmentation and conflict of Islamic political parties during the era of Reformasi with that during the Old Order. From the age of the Old Order until the days of Reformasi, Muslim leaders have continually failed in their quest of uniting the Muslim voice till it became a solid political bloc. Their early enthusiasm during the Old Order, as

\footnotetext{
48 Ahmad Fauzi Abdul Hamid, "Religion, secularism and the state in Southeast Asia," in Arlene B. Tickner and David L. Blaney (eds), Thinking International Relations Differently (London and New York: Routledge, 2012), pp. 253-256.

49 Ali Masykur Musa, “(Bukan) Kegamangan Politik Islam,” Republika, August 3, 2009.
} 
expressed in the establishment of Masyumi, which in certain aspects parallels the Reformasi-era development pertaining to the formation of pragmatic Poros Tengah, evaporated once it became evident that political wheeling and dealing took the better of them than the Islamic call for unity. Fragmentation and conflict of Islamic political parties were the order of the day, and in today Reformasi period, these splits and tussles were palpably demonstrated to the Indonesian nation during successive legislative and presidential elections.

Conflicts that arose among Islamic parties ranged from issues such as ideological differences, policy variations and elite competition. In the case of $\mathrm{PKB}$, the pivotal factor was concentration of power in the hands of one leader i.e. Gus Dur, who acquired the habit of flouting his party's own rules. Dispersal of the political strength of Islamics during the presidential elections was also motivated by the widely spread desire of gaining short term spoils of power, for example in the distribution of cabinet positions.

The fragmentation and conflict discussed in this article had undesirably relegated the importance of the Islamic voice vis-à-vis that of the nationalist bloc. Ideology is no longer rule of the game. In their soul-searching and self-introspection following the negative ramifications from their falling out with one another, Muslim politicians need to mirror their own actions and attitudes against Islam's own moral code. With so-called Muslim politicians themselves being implicated in a host of sex and graft scandals, not to mention the infighting among them, one cannot blame lay people on the street's perception of Muslim politicians as being no different from their secular counterparts. With no obvious difference between both cohorts of leaders on the personal morality scale, a voter is bound to choose leaders who can give them a better deal on bread and butter issues, rather than elect politicians who are good at pontificating but falter in the delivery of tangible goods and needs. []

\section{References}

\section{Books and Articles}

Azra, Azyumardi. Reposisi Hubungan Agama dan Negara: Merajut Kerukunan Antarumat. Jakarta: Kompas, 2002.

Budiardjo, Miriam. Dasar-Dasar Ilmu Politik. Jakarta: PT. Gramedia Pustaka Utama, 1991 
Djawamaku, H. Anton. "Perpecahan Partai Politik, Pemberantasan Korupsi dan Berbagai Masalah Politik Lainnya." Analisis CSIS, vol. 34, no. 2 (June 2005): pp. 126-129

Haidar, M. Ali. Nahdatul Ulama dan Islam di Indonesia. Jakarta: Gramedia Pustaka Utama, 1998.

Hamid, Ahmad Fauzi Abdul. "Religion, secularism and the state in Southeast Asia." in Arlene B. Tickner and David L. Blaney (eds). Thinking International Relations Differently. London and New York: Routledge, 2012.

Kamarudin. Konflik Internal PKB. Jakarta: AksesPublishing, 2008.

Kirbiantoro, S., and Dody Rudianto. Pergulatan ideologi Partai Politik di Ideologi Partai Politite di Indonesia: Nasionalisme, Islamisme, Komunisme, Militerisme. Jakarta: Inti Media Publisher, 2005.

Lembaga Survei Indonesia. Kekuatan Elektoral Partai-Partai Islam menjelang Pemilu 2009. Jakarta, September 2008.

Mashad, Dhurorudin. Akar Konflik Politik Islam di Indonesia. Jakarta: Pustaka Al Kautsar, 2008.

Romli, Lili. Islam Yes, Partai Islam Yes: Sejarah Perkembangan Partai-Partai Islam di Indonesia. Jakarta: Pustaka Pelajar, Pusat Penelitian Politik LIPI, 2006.

Sjamsuddin, Nazaruddin, Zulkifli Hamid and Toto Pribadi. Sistem Politik Indonesia. Jakarta: Karunika, Universitas Terbuka, 1988

Ulum, Bahrul. 'Bodohnya NU', apa 'NU Dibodobi'?. Yogyakarta: ArRuzz, 2002.

Zamjani, Irsyad. Sekularisasi Setengah Hati. Jakarta: Dian Rakyat, 2009.

\section{Internet Sources}

Agustiar, Dwi Riyanto. "PKB Kubu Muhaimin Segera Bawa Hasil Muktamar ke Departemen Hukum." May 4, 2008, http://www.tempointeraktif.com/hg/nasional/2008/05/04/brk,20080504-122433,id.html, accessed on July 10, 2010.

Anggaran Dasar Partai Amanat Nasional, http://pan.net46.net/index.php?view $=$ article $\&$ catid $=29 \% 3$ Aanggaran-dasar\&id $=22 \% 3 \mathrm{~A}$ asas-dan-tujuan\&option $=$ com content $\&$ Itemid $=37$, accessed 5 March 2009 
"Departemen Hukum Sahkan Kubu Muhaimin." Tempo, June 25, 2008, http://hukumham.info/index.php?option $=$ com content\&tas $\mathrm{k}=$ view\&id $=1073 \&$ Itemid=99999999, accessed on March 4, 2009.

Effendi, Bachtiar, "Gus Dur tidak salah", http://www.inilah.com/, accessed on March 4, 2009.

Ferdian Andi R, “Kisruh di PPP? Sudah Tradisi!”, September 19, 2008, http://www.inilah.com/berita/pemilu-2009/2008/, accessed on March 4, 2009.

Hemay, Idris, "Pertarungan Parpol Islam 2009", http://www.csrc.or.id/artikel/, accessed on March 4, 2009.

Karni, Asrori S., "Partai Kebangkitan Bangsa: Manuver Gus Dur Menggoyang Muhaimin", Gatra, no. 36, July 25, 2007, http://www.gatra.com/2007-07-25/artikel.php?id=106372, accessed on March 4, 2009.

Permata, Phil Ahmad Norma Pemata, "Kegagalan Partai Islam", Shohifah, Suara Mubammadiyah, http://suara-muhammadiyah.com/2010/?p=593, accessed on March 4, 2009.

"PKB, Berpartai di Tengah Konflik", http://www.hupelita.com/baca.php?id $=55400$, accessed on July 10, 2010.

\section{Newspapers and Magazines}

Musa, Ali Masykur, “(Bukan) Kegamangan Politik Islam”, Republika, August 3, 2009.

Setyawan, Bambang, "Pergeseran Kekuatan Partai Nasionalis dan Islam, 1955-2004”, Kompas, September 15, 2008.

Kompas, January 11, 2002

Republika, February 29, 2008.

Tempo, July 28 - August 3, 2008.

Majalab Tempo, April 14-20, 2008.

Majalah Tempo, July 7-13, 2008.

Majalah Tempo, July 21-27, 2008.

Majalah Tempo, March 17-23 2008. 